\title{
The Recolonization of the Indian Mind
}

A recolonização da mente indiana

La recolonisation de la pensée indienne

Peter Ronald deSouza

\section{(2) OpenEdition}

\section{Journals}

Electronic version

URL: http://journals.openedition.org/rccs/6809

DOI: $10.4000 /$ rccs.6809

ISSN: 2182-7435

Publisher

Centro de Estudos Sociais da Universidade de Coimbra

Printed version

Date of publication: 1 December 2017

Number of pages: 137-160

ISSN: 0254-1106

\section{Electronic reference}

Peter Ronald deSouza, "The Recolonization of the Indian Mind ", Revista Crítica de Ciências Sociais [Online], 114 | 2017, Online since 20 December 2017, connection on 21 December 2020. URL : http:// journals.openedition.org/rccs/6809; DOI : https://doi.org/10.4000/rccs.6809 


\section{PETER RONALD DESOUZA}

\section{The Recolonization of the Indian Mind}

One of the most pernicious consequences of colonialism was what K. C. Bhattacharya described as the 'enslavement of minds'. It produced a feeling of inferiority, an erasure of memory and cultures, an alien conceptual vocabulary and a hegemonic perspective from which to view the world. This article describes these consequences in some detail to demonstrate the huge conceptual challenges that a decolonisation of the mind has to confront as it attempts to move the society, and public discourse, towards a truly emancipatory future. In addition to these conceptual challenges the article also describes the worrisome new recolonisation of the Indian mind that is taking place by the knowledge producing agencies that are outside the university and that are driven by the interests of global capital in its unrelenting desire for domination. These knowledge agencies produce a discourse that is embedded in interest and, in a grave departure, is delinked from the pursuit of truth.

Keywords: colonialism; decolonization; global capital; India; K. C. Bhattacharya (1875-1949).

\section{Introduction}

In the Sir Ashutosh Memorial lecture entitled 'Swaraj in Ideas', delivered in 1931, the eminent Indian philosopher K. C. Bhattacharya lamented the impact on India of the colonial encounter with Europe. Two consequences deeply concerned him. The first he referred to as the enslavement of the mind, which, he believed, was worse than political subjection since the latter only meant restraint on the 'outer life of the people' whereas in the case of the enslavement of the mind "slavery begins when one ceases to feel the evil and it deepens when the evil is accepted as a good". The second harmful consequence for him was the replacement of the real mind by the shadow mind "that functions like a real mind except in the manner of genuine creativeness" (Bhattacharya, 1954: 2-4).

Reading the lecture in the present times, and recognizing that my existential location in post-colonial Goa, I was left by anxious, angry and curious. I was anxious to know whether the process of enslavement had indeed ended, now that we were independent, or whether it still continued, and if it did, 
whether resistance to enslavement looked like: a self-conscious nativism, or a deliberate eclecticism, or perhaps a constructed cosmopolitanism? I was also angry because the long period of colonialism made me feel disconnected from the intellectual life of India that is constituted by plural philosophical systems, that has many schools of thought in it, that is rich in its epic literature, and that has a vibrant folk tradition and dissenting culture. Colonialism has disconnected one from this intellectual universe and, therefore, re-establishing a connection so that one can speak to today's concerns is fraught with political pitfalls. In addition to such anger and anxiety I also carry some ambivalence towards the historical encounter. From today's ethical framework I must also recognize the emancipatory possibilities that it produced, e.g., the Portuguese colonial state's abolition of Sati, a practice where widows were expected to immolate themselves on the funeral pyre of their dead husbands. This, which was done 200 years before Bentinck abolished it in British India, ${ }^{1}$ and the introduction of the Common civil code that gave women equal rights to property, are obvious examples. ${ }^{2}$

Coupled with such anxiety and anger was a third emotion, curiosity. ${ }^{3}$ I was curious to investigate the social and historical nature of the processes that had brought us to such a pass. Did they still persist today, and do they do so in the same form, or had they actually assumed a different form with dif-ferent instruments of domination having emerged in a new and more subtle, and more perfidious, neo-colonial relationship? If the intellectual concern in India was the struggle and yearning for freedom of the mind, I thought, let me begin my investigation and look for similar anxieties expressed elsewhere in the colonized world. Thus this paper will have three sections. I will begin with a brief discussion of the concerns expressed by thinkers in other regions of the colonized South. I will then look at attempts at decolonization in India, and finally, at some greater length, I will examine the situation in India today.

\section{Colonization of the Mind}

Franz Fanon saw the colonial relationship as producing the false belief that concepts travelled to other parts of the world, from Europe to outside Europe, as if they were baggage-free, not carrying the cultural markers of their place of historical origin. The myth that was promoted was that the conceptual schemas of Europe, their normative goals, were valid for the whole world. By buying into them, we, the colonized

\footnotetext{
${ }^{1}$ In 1829, the Bengal Code was promulgated in British India rule by the then Governor-General Lord William Bentinck which made the practice of sati illegal and subject to prosecution.

${ }^{2}$ F. E. Noronha (2008), Understanding The Common Civil Code. Nagpur: AIR.

3 On this topic see Manguel's 2015 book, Curiosity.
} 
people, developed an idiom and a vocabulary that was alien to us since we either abandoned our own schema or allowed it to atrophy. We may have black skins but we had begun to wear white masks. Fanon, with the anguish of a victim who has to encounter the loss of self-worth caused by colonialism, wrote:

Out of the blackest part of my soul, across the zebra striping of my mind, surges this desire to be suddenly white.

I wish to be acknowledged not as black but as white.

Now ... who but a white woman can do this for me? By loving me she proves I am worthy of white love. I am loved like a white man.

I am a white man. ...

I marry white culture, white beauty, white whiteness.

When my restless hands caress those white breasts, they grasp white civilization and dignity and make them mine (Fanon, 1967: 63).

In similar vein, and expressing a similar angst, Aimé Césaire in his classic study, Discourse on Colonialism (1972), also reflected on this theme when he argued that the system of ideas that accompanied colonialism constructed the non-west as primitive, as the inferior other, and as a consequence placed on Europe the burden of bringing civilization and all its accoutrements to this inferior world. By giving these inferior peoples a conceptual language, and by training them in the cultural practices that were a hallmark of civilized peoples, Europe was able to create images of itself in other regions of the world. This was the white man's burden that drove the colonial encounter. ${ }^{4}$

Tristao de Braganza Cunha from Goa, regarded as the father of the struggle against Portuguese colonialism, saw this encounter with Europe as leading to the "Denationalization of Goans". In the pamphlet of the same title he argued that systematic colonial state policy, imposed through various coercive means including the Inquisition, which was also visited on Goa, led to the erasure of the cultural memory of Goans and so to their cultural amnesia (Cunha, 1961). This disconnect was a huge loss, since it closed off an engagement with aesthetics, ethics, logic, and poetics that were such a rich part of the civilization landscape of India. For him a people that had lost connection with

${ }^{4}$ The phrase comes from the poem 'The White Man's Burden: The United States and the Philippine Islands' which was written by Rudyard Kipling in 1899 to justify the colonial project, which was seen as a noble enterprise. 
their intellectual and cultural heritage were a people that had become denationalized. ${ }^{5}$

The Kenyan writer Ngugi wa Thiong'o, in his Decolonising the Mind, describes the impact of the colonial educational system and curriculum on the native mind. He narrates the story of how African students who had studied English Literature - Shakespeare, Milton, Wordsworth, Shelley, Keats, and Kipling, the whole pantheon of British greats - "had been able to recognise some characters of Jane Austen's novels in their own African villages" (1986: 91). Was Ngugi raising the possibility that this very English novelist, who we were told had confined herself to describing the world of the English landed gentry was also, in fact, describing characters with universal human traits who, shorn of the costumes of the English landed class, were discernible to the African student? ${ }^{6}$ For Ngugi, the danger of the colonial system of education lay in its control over perception, over the ways in which those who had been subject to its spell saw the world. A European perspective became the lens through which they made sense of the world. Shiva Naipaul illustrates this well with his discussion of how language changed even geography. The nation of the 'highlands' to describe a region that had been roamed by the local people around Mt Kilimanjaro in East Africa, became, with colonialism a distinct region suitable for the white settlers and distinct from the lowlands where the natives lived. ${ }^{7}$

Another thinker, the Palestinian philosopher and literary theoretician Edward Said, in a powerful critique of anthropology's service to the colonial powers, wrote that to be "colonised is potentially to be a great many different, but inferior, things, in many different places, at many different times". Colonialism produced "[...] the dreadful secondariness of people who, in V. S. Naipaul's derisive characterisation, are condemned only to use

\footnotetext{
5 A similar argument was made by Abd-ur-Rashid Moulvi (1888). His essay on "The Punjab University" expressed the concern with the 'anglicizing tendency' of the Calcutta university, a tendency that the author felt ran the risk of a 'denationalization of the younger generation of Punjabis'. To counter such denationalization, the people of Punjab wanted that the literatures and science be taught in the vernaculars and classical languages. Unfortunately this did not happen. ${ }^{6}$ In a column in the Bangalore Mirror, of 29 April 2016 (http://bangaloremirror.indiatimes.com/ columns/views/Shakespeare-after-Shakespeare/articleshow/52046055.cms), Chandan Gowda reminisces about the impact Shakespeare and Shakespeare scholars had on Kannada intellectuals who studied English at university: "Shakespeare arrived in India, of course, as part of the British colonial enterprise [...] but he did not remain the monopoly of the British", as Shakespeare plays were translated into Kannada.

${ }^{7}$ In his travelogue about Africa in the book North of South: An African Journey (Penguin Classics, 1996), Shiva Naipaul describes how this phrase changed the perception of the natives of the geography of their land.
} 
a telephone, never to invent it" (2001: 295; emphasis mine). The themes of inferiorization, of only wanting to imitate the West, and of cultural erasure of native traditions, are themes that connect much of the writing of thinkers from across the colonized world.

A new but important dimension is, however, introduced into the discussion by Albert Memmi, the Tunisian writer, in his semi-autobiographical novel, The Pillar of Salt (1992). His central character, Benillouche, believed that by rejecting his different identities, i.e., distancing himself from his Arab, African and Tunisian-Jewish heritage, he would be better equipped to move ahead in the world, invested deeply in mastering the curricula and texts that were a part of the uniform French educational system. If distancing himself from his intellectual and cultural world was what was required to excel, Benillouche was prepared for this sacrifice. He worked very hard at mastering the seminal texts and the philosophical systems of the Western Academy. However, when the conflict of the second World War in Europe came to his country and the world of his birth came into conflict with the world of his learning, all his achievements in the world of scholarship were not enough to protect him from the bigotry and bias of the French colonial authorities that followed the coming of the Nazis. European philosophy and philosophers deserted him when he needed them most. When they were called upon to stand up for him - for equality, liberty and fraternity - they preferred to remain silent in the face of Nazi power.

The failure of this European intellectual world, from Descartes to Mill, to protect the colonized subject from the tyranny of the colonial state, and the discovery that European intellectuals, or rather intellectuals who reside in the colonial metropolis, lead a split existence, talking ethics but practicing prudence in the face of tyrannical power, is something the post-colonial society needs to recognize. This 'betrayal' by European philosophy and philosophers which recurs in the many stories of slavery (some of the authors of the American Constitution, including the Bill of Rights, were slave owners), colonialism (James Mill, the Utilitarian philosopher, was Head of India House in London), exclusion, and even affiliation with Nazism (as was the case of Heidegger) ${ }^{8}$ where the commitment to the pursuit of truth is ceded to rationalization, by some of the European philosophers mentioned, of the exercise of power, is a paradox that needs to be probed beyond the knowledge/power paradigm of Michel Foucault (1984).

\footnotetext{
${ }^{8}$ Elisabeth Young-Bruehl in her book Why Arendt Matters (Yale University Press, 2009), describes how Heidegger does not apologize for his association with the Nazis and prefers silence to explanation for these views of his.
} 
Why is Western philosophy so schizophrenic, so vocal when in the classroom but so silent when in the colonial streets? This is not to imply hypocrisy on the part of the intellectual class, not make a charge of 'treason' as Julien Benda (1955) made, but to point to a paradox at the heart of philosophy. A point comes, in the pursuit of truth, when the routinization of that which is a dominant mode of being i.e., the pursuit of truth that leads to daily protest of what is, if not daily rebellion, becomes too unsettling. This is also a struggle for intellectuals in the global South.

What I have sought to do in this brief, but illustrative, sketch is to draw out the key arguments made by the thinkers mentioned and then to see whether these remain valid for the contemporary post-colonial world. It was a brief tour through the intellectual landscapes of worlds colonized by the British, French and Portuguese. The colonial project in each world was to create a little Europe in distant lands. It succeeded fully in many countries, look at Australia and Argentina, and partially in others, producing a comprador elite that served the colonial project.

The brief survey summarizes the many specific responses that have been given to the question, what did colonialism do to the native mind? It enslaved the native mind, making it believe that what had emerged in the colonial encounter was good. It produced a shadow mind whose creativeness was eroded and which, unknown to itself, adopted an intellectual life that was marked by imitation and mimicry. It led to an erasure of cultural memory, producing disconnect with a millennia-old intellectual and cultural life. It gave the (mistaken) impression that the concepts that inhabited the European intellectual universe, particularly those that had their origin in the Enlightenment, were context-free and had universal validity. It made the colonized people feel that their cultures were inferior and that abandoning them, and adopting the cultural practices of the colonizer was, therefore, the way to go if one wanted to be respectable and be accepted as civilized. If colonialism had these effects on the mind, how was decolonization of the mind to be effected?

\section{Decolonization of the Mind}

The extent of such colonization, I am not sure, was widely understood since it has seeped into the sub-conscious mind. It created a new language of representation replacing earlier languages. Its conceptual vocabulary, and its meaning systems, began to dominate thinking in the post-colonial world. The task of exorcising the many ways in which the feeling of inferiority had seeped into our cognitive world, of restoring memory and connection with a native cultural landscape by recognizing discontinuities and identifying continuities, and finally the task of building alternative cosmologies rid of 
the orientalism that pervades the dominant discourse in the humanities and social sciences today, is an enormous one. We have still to forge the analytical tools for this decolonization of the mind.

While there has been some pushback in the Spanish- and Portuguesespeaking world, where a number of scholars have initiated an intellectual exercise of building an 'epistemology of the South' (Santos, 2014), no such concerted and sustained effort has emerged in the Anglophone world. In mounting their critique by introducing ideas such as 'colonial difference' (Mignolo, 2002), 'transmodernity' (Dussel, 2013), 'coloniality of power' (Quijano, 2000) or the 'ecology of knowledges' (Santos, 2014) they have expanded the discussion of how to decolonize the mind. I do not wish to go into the nuances of this debate in this Latin world, because it is complex and rich, but I find some of the insights that are offered, such as that of Boaventura de Sousa Santos on looking at 'ignorance' differently, playful and of considerable interpretative potential. This seems the way to go.

The ecology of knowledges is founded on the idea that there is no ignorance or knowledge in general; every kind of ignorance ignores a certain kind of knowledge and every kind of knowledge triumphs over a particular kind of ignorance. Learning some kinds of knowledges may imply forgetting others and ultimately ignoring them. In other words, concerning the ecology of knowledges, ignorance is not necessarily the original condition or starting point; it may well be the point of arrival. That is why throughout every stage of the ecology of knowledges it is crucial to ask if what is being learnt is valuable, or should be forgotten or not learnt. Ignorance is merely a discredited form of being and making when what has been learnt is more valuable than what is being forgotten. The utopia of inter-knowledge is learning other knowledges without forgetting one's own. (Santos, 2012a: 57)

This play between knowledge and ignorance, as discussed in the above quote, suggests a play of power between hegemonic perspectives and subaltern ones, between those seeking to control and those unable to resist. The vibrant debate emerging in the Latin world needs to be similarly conducted in the intellectual theatre of South Asia. The occasional interventions by Ashis Nandy, Gopal Guru, Partha Chatterji, Sudipta Kaviraj, Shiv Vishwanathan, Dipesh Chakrabarty, and others, has established a beachhead and needs considerable expansion. This has not happened. As a consequence, unfortunately, there is a neo-colonial takeover of the post-colonial knowledge space by the knowledge producing centres of the metropolis. The 'occupy' and the 'indignados' movements need to spread to the knowledge world of the social sciences. 
However, I shall, at this point, step back from these contemporary excursions and return to the intellectual history of India. The discomfort with this colonial encounter with Europe produced in India a range of responses, from glorifying Indian tradition - a sort of nativism - to rejecting the tradition because it was gross - embracing orientalism - to trying to take what was best in both and attempting a fusion of forms - eclecticism (Parekh, 1999). If these different responses were to be organized into broad clusters, then we can possibly identify three clusters. The first, best exemplified by the writings of Rabindranath Tagore and Mahatma Gandhi, sought to build an alternative knowledge system that was organically linked to the culture and the needs of our society. This cluster was closest to the 'enslavement of minds' thesis of K. C. Bhattacharya insofar as it attempted to break free from such enslavement by constructing a comprehensive alternative. I shall discuss Tagore's view on an Indian university in more detail later.

The second cluster, in contrast, does not recognize or appreciate the full extent of such enslavement. It buys into the promise of the Enlightenment ideals and sees its task as merely the tweaking of the knowledge system introduced by the colonial state, to align it better with the goals of national development. This cluster accepts the claim that the content produced by these knowledge practices is neutral because it follows the rigorous protocols of science and hence its politics lay in the system and not in the content produced. Hence all that was required of the post-colonial state was to re-orient and re-direct the system to meet the goals of a post-colonial society. This epistemic innocence did not even notice the set of prejudices embedded in concepts, i.e., the baggage they carry with respect to the value biases of the societies in which they have emerged. ${ }^{9}$ It is an innocence that is most widespread in independent India. It underlies our educational policies, institutions, and initiatives. A national curriculum, accompanied by a frenetic building of the temples of modern India, i.e., institutes of technology and modern universities based on the templates of the North, are considered adequate initiatives to decolonize the mind. In other words, by pushing this educational policy frame developed by the North for their own universities, our policy makers and educational bureaucrats have become accomplices in the further colonialization of our minds. The Pitroda-led National Knowledge Commission (NKC) reports are the best statement of this. ${ }^{10}$

\footnotetext{
9 The 'scientific temper' statement issued by P. N. Haksar, Raja Ramanna, and P. M. Bhargava, on July 19, 1981, where the concern at the 'accelerating pace of retreat from reason' in India was expressed, exemplifies this position.

${ }^{10}$ See the National Knowledge Commission website, at http://knowledgecommissionarchive.nic.in.
} 
The third cluster takes on a more rejectionist position with respect to the curriculum that has been prepared in the global North and seeks to develop an alternative curriculum in the humanities and the social sciences (Alvares, 2001). Unfortunately, because of the power of the neo-colonial frame, it has little presence in the educational landscape in India today. This weak presence is a reflection of both the Northern vision's continuing power over the mind and the inability of the alternative to attract intellectual and financial support.

The difference between the three clusters depends on their recognition of the 'extent' of the colonization of the mind that has taken place. It is this recognition that underwrites the validity of the package of policies, curricula and institutions that have been initiated to decolonize it. To discuss each of these three clusters would be a lengthy exercise for which there is no space here. I shall limit myself, in this essay, to a brief presentation of Tagore's views on education.

Tagore was severely critical of the model of the university imposed by the colonial system in India and felt that an alternative institution was needed to fully align the educational system with a dynamic and creative Indian culture so that it could achieve national aspirations. Vishva Bharati was the university he set up on the basis of this understanding and he linked it with the pre-university education process in the town of Shantiniketan. Tagore saw the colonial encounter in the following terms. Let me quote him at some length to convey the sense of his despair.

The European culture has come to us not only with its own knowledge but with its velocity. Though our assimilation of it is imperfect and the consequent aberrations numerous, still it is rousing our intellectual life from its inertia of formal habits into glowing consciousness by the very contradiction it offers to our own mental traditions. What I object to is the artificial arrangement by which this foreign education tends to occupy all the space of our national mind and thus kills, or hampers, the great opportunity for the creation of a new thought power by a new combination of truths. It is this which makes me urge that all the elements in our own culture have to be strengthened, not to resist the Western culture, but truly to accept and assimilate it, and use it for our food and not as our burden; to get mastery over this culture, and not to live at its outskirts as the hewers of texts and the drawers of book-learning. (Tagore, 1996: 486)

Being a man of literature, Tagore was a master of metaphor, which he used to great effect in his polemics against the colonial system of education. An alien education, he believed, left the colonized people as 'mental 
cripples' and therefore it was necessary to create both a curriculum and teachers who would teach in the languages of India. Language, for him, was "not like an umbrella or an overcoat, that can be borrowed by unconscious or deliberate mistake; it is like the living skin itself" (Tagore, 1996: 564). For Tagore the colonial educational system trained us not to "produce but to borrow' (ibidem: 562). This he sought to overcome at Vishva Bharati which he set up in 1921. It has produced many illustrious alumni such as Amartya Sen, Mahasweta Devi, and Satyajit Ray.

My objective in mentioning these three clusters is to draw attention to the challenge of the decolonization exercise. The first cluster produced experiments such as Visva Bharati, which has had limited success and has now, as the post-colonial state asserts its own inner logic and its own dynamics of power, begun to face a series of contradictions. Do these contradictions exist because Vishva Bharati is a lone institution in a sea of institutions that have only marginally departed from the colonial road map for such institutions, and therefore does not have the critical mass to resist the domination even now that political colonialism has ended? Or is it because the political sociology of institutions, particularly in India, soon begins to assert itself as people jockey for power and thereby overwhelm the idealism that marked the founding of the institution, reducing it to the feeble imagination of its current operators? Or is it that the post-colonial state, in its zest to standardize practices of educational delivery and maintain central control, has debilitated the institution irreversibly by giving it funds but taking away its soul?

The second cluster, which adopted an incremental approach of merely tweaking the inherited structure of education and knowledge production, achieved little by way of breaking free from the enslavement of the mind and has, in fact, created the ground for a subsequent recolonization. Is this because the paradigm of knowledge creation articulated by the colonial regime is essentially valid and all other competing paradigms are deemed unsustainable? The global picture seems to give credence to this argument as educational systems across the world adapt and adopt the knowledge systems of the global North. The third cluster, which attempts a radical alternative, has made little headway in India either because the institutional power opposed to it - what Edward Said (1986: 52) refers to as a 'wealthy system of interlocking informational and academic resources' - was too massive or because it was insufficiently developed to attract supporters? These are complex questions which will need to be investigated in a longer study. Irrespective of the dismal findings of the survey - to wit, that the knowledge systems of the North have conquered knowledge spaces across 
the global South -, the fact remains that minds in the South (and here it is useful to see the South as a metaphor according to which even in the geographical North there is a South) have been colonized.

The preceding sections were intended to serve as a preface to the discussion that will follow on the recolonization of the Indian mind. Let me briefly list ways in which this process can be encouraged. There are five general strategies that can be adopted which I label (i) incrementalist, (ii) subaltern, (iii) nativist, (iv) inspired eclectic, and (v) the counterdiscourse. I will now briefly comment on each.

In the first, the incrementalist strategy of resistance, one engages with the Northern discourse and looks within it for inconsistencies, ambivalences, and inconvenient facts in it. Through this search one can sow the seeds of alternative readings, expose the biases and contradictions of the dominant frame, and provide the grounds for arguing for different cosmologies. The political sociologist Susanne Rudolph (2005) labeled these biases of the North as the 'imperialism of categories'. She complained that their methodological training in the North left students quite unprepared for the experiences of data collection in the alien field of South India. She wondered "To what extent were the tool kits we brought with us from the United States capable of bridging differences between civilizations, cultures, and worldviews between the Western observer and the non-Western observed?". Since concepts can be capacious, infiltration, adaptation, and modification may, in principle, be possible. The task before us is to build up the inconvenient facts' that these concepts from the North have to confront. This involves hard labor. Unfortunately our social science culture in India expects us only to prove the theories of the North. This attitude must change.

The second, the subaltern strategy, has worked well and has now become the default mode of history writing in many locations of the South. Such history writing is important because the victors write history and this must be countered in such a way that the colonialists are held to account and their historical narratives besieged by alternative and parallel stories.

What is clearly left out of this un-historical [elitist] historiography is the politics of the people. For parallel to the domain of elite politics there existed throughout the colonial period another domain of Indian politics in which the principal actors were not the dominant groups of the indigenous society or the colonial authorities but the subaltern classes and groups constituting the mass of the labouring population and the intermediate strata in town and country - that is, the people. This was an autonomous domain, for it neither originated from elite politics nor did its existence depend on the latter. (Guha, 1997: 37-38; my addition) 
The third, the nativist approach, is politically very delicate since it can lead both to a vulgar nationalism and to an insightful philosophical reading of native texts. The vulgar nativism is best demonstrated by the statement made by Dinanath Batra after he met the Minister of Human Resources Development in June 2014 and he demanded the rewriting of history textbooks to get the 'balance back' since the current history is "the work of Marx and Macaulay's sons [sic]. The books are not rooted to the culture of the land." "11 The aim of his movement is to bring about an Indianization of education and to remove the vestiges of colonialism.

While this argument may, on a first reading, seem similar in sentiment to the one that I am making on decolonization, a second reading reveals that it is actually a movement to glorify a sectarian reading of the past, erasing other histories and contributions such as those of the encounter with Islam. The Indian past is a past of conquests, domination, achievements and suppressions, and can be regarded as a palimpsest in which many histories are written and never completely erased and all of these, with their blood and glory, must be recovered. ${ }^{12}$ In contrast to this crass nativism is the brilliance of A. K. Ramanujan (1989), whose essay "Is there an Indian Way of Thinking?" sets out arguments of other universals that are emerging from the Indian intellectual landscape, where time and space also play a part in their construction.

The fourth strategy, inspired eclecticism, is best demonstrated by the essays of Edward Said, a point of reference on how one can live a hybrid existence with a foot in each civilization zone and still lead a fertile intellectual life. I call this an 'inspired eclecticism' because it takes from everywhere and submits to critical scrutiny that which it takes, and then uses what it has taken. It does so in a new and inspired way, revealing aspects of the human condition that it has intuitively sensed and without falling prey to the dominant frameworks of knowledge and power. According to Said,

one of the major roles [...] for the intellectual in the public sphere is to function as a kind of public memory; to recall what is forgotten or ignored; to connect and contextualize and to generalize from what appear to be the fixed "truths" $[\ldots]$ the isolated story, and connect them to the larger processes which might have produced the situation that we're talking about [...] it falls to the intellectual to make the connections that are otherwise hidden. (2001: 503)

\footnotetext{
${ }^{11}$ See http://www.ndtv.com/india-news/told-smriti-irani-history-books-must-change-saysmanbehind-ban-on-wendy-doniger-book-593826? site=full.

${ }_{12}$ Batra is opposed to these multiple and alternative readings.
} 
There is, therefore, much work for the intellectual in the global South to do. Arindam Chakrabarti is up to the challenge and his work is an embodiment of such inspired eclecticism. In the recent book that he has co-edited with Ralph Weber, Comparative Philosophy without Borders (2015), he stages a set of insightful conversations between different philosophical systems from both the North and the South. It is this seamless travel across intellectual systems, driven by philosophical questions such as 'how do we read others' feelings' or 'how can one represent another', that constitutes the challenge because such travel requires one to get past border controls and to ensure that one's philosophical documents are in epistemic order.

The fifth - the counterdiscourse - refers to the work of the scholars from the Latin world mentioned earlier. They have progressed a considerable distance in laying out the road for the epistemology of the South. They have been aided by Indian scholars, also mentioned earlier, but these have established only the beachheads and have not produced the collective effort required to re-occupy the space currently dominated by a social science and humanities discourse from the North which can be seen in the curricula, vocabulary, and strategies of representation of our world, that are prevalent in social sciences in India. The counterdiscourse has to fight on many fronts. It has to avoid the pitfalls of a vulgar nativism. It has to endorse the insights of an inspired eclecticism. It has to accommodate the interpretations coming from incrementalism. It has then to put all these together in order to offer readings that are different from those coming from the North, that are richer in their understandings of social processes, and that also speak to our contemporary concerns. This is what the struggle to decolonize the mind involves. The challenge is to learn how to do so and to acquire a habit of 'infiltrating, adapting and modifying concepts' that seems to work, while keeping in mind that such adaptation does not produce cooption by the knowledge/power frameworks of the North.

In recent years, while these old battles of the mind are being waged, a new front has opened up. If the earlier battles were about the inferiorization of the subjugated by colonialism, the new battle is about the inferior developmental path that the newly independent nation has chosen. If the earlier relationship of domination sought to establish the superiority of the institutions of colonialist, the new relationship seeks to establish the superiority of the ways of global capital.

In the present globalized world the interests of global capital enter and take over the production of knowledge, the control of perception, and the direction of policy discussions in the public sphere. The logic of the long prelude to this paper has been to bring the discussion to this point where 
I can describe the processes of the recolonization of the Indian mind. There are two parts to these processes: (i) to establish the inferiority of contending pathways, and (ii) to do so by taking over the public policy spaces that are crucial to the formulation of futures for our countries.

\section{Recolonization of the Mind}

Let me begin my case by offering three illustrations. In an interesting article entitled "Left out of the Rankings", ${ }^{13}$ of 2014, Professor Bhaskar Ramamurthi, Director of the prestigious Indian Institute of Technology (IIT), Madras, challenged the international methodology used to rank universities. His argument was that certain parameters are included in the methodology while others, which we may consider valuable for our national development, are excluded. How were such parameters chosen and by whom, and according to what set of guidelines, he asked? Who was to determine what parameters were to be included and which excluded? The process of ranking of knowledge institutions so far is fairly opaque, yet its results are treated as objective and receive global validation. Any discussion of ranking must, therefore, begin with an examination of the grounds for the parameters used. Why are some parameters, which from a national perspective we consider relevant, missing from the evaluation matrix? Is this methodology of ranking institutions reflective of the global politics of knowledge production?

To get into an IIT in India, for example, candidates must pass the JEE examination. ${ }^{14}$ This is a very difficult examination, and several hundred thousand students spend many years preparing to compete for a few thousand seats. It is an egalitarian exercise and does not depend on the candidates' social power or family wealth. In contrast, not all candidates who get into USA Ivy League (IL) institutions get in on high SAT ${ }^{15}$ scores. They must be able to pay for the education (rely on a bank loan or family wealth) and also have excellent references. The matrix for admission at an IL weighs SAT scores (excellence), funding ability (wealth), social status (power), and capacity to promote the institution's interests (networks). ${ }^{16}$

If a five-year data set on applications and admissions to IL institutions was available, it would show the trend discussed above, of proportionate weight

\footnotetext{
${ }_{13}$ Published in the Indian Express, 24 June 2014.

${ }^{14}$ The Joint Entrance Examination (JEE) is an engineering entrance examination conducted for admission to various engineering colleges in India.

${ }_{15}$ The Scholastic Aptitude Test (SAT) is an entrance examination required to all candidates applying to USA universities.

${ }_{16}$ See https://www.alternet.org/corporate-accountability-and-workplace/chomsky-how-americasgreat-university-system-getting and https://www.theatlantic.com/education/archive/2016/04/ the-pillaging-of-americas-state-universities/477594/?utm_source=SFFB
} 
given to excellence, wealth, power and social network. ${ }^{17}$ In contrast, since the IITs only value JEE scores, aren't the IITs superior and more egalitarian? Further, if a candidate wants to challenge the admission process in India i.e., the JEE ranking -, she can apply, under the Right to Information law (RTI), for details on who was admitted and under what criteria. The policy of reservations is another important parameter that must be brought into any ranking exercise. Surely normative issues such as these should be key elements of any ranking exercise, especially since they reward excellence, provide access, see education as a public good, and link the benefits of education to the public interest (UNESCO, 2015).

But the Indian public discourse of both policy planners and academics does not raise these counter issues on the relevance of the parameters. For example, there is an interesting discussion on higher education as a 'public good' in South Africa and Brazil, which determines the funding and structure of educational institutions. Does the policy of treating higher education as a 'public good' enter the ranking methodology? And why is it not debated at this level by the policy and academic community in India? I suspect because our minds have been re-colonized by the neoliberal discourse whose view of the world is regarded as the best and only view. Not only is there an enslavement of our policy thinking, the global ranking index also produces a sense of inferiority about Indian institutions. Professor Ramamurthi's article was to challenge such perception.

While I have singled out this case as an illustration, I want it to lead us to the larger point of how frameworks of evaluation are constructed by ignoring other needs and value premises, such as, in this case, education for citizenship. The community college movement in the USA, which does not come into these rankings, has brought access and opportunity for self-development to large numbers of the disadvantaged and yet is not on the radar as one of the 'best universities'. Further, the universities ranked highly on the global rankings index serve as models for policy makers across the global South who try and re-work their policy frames to push public university education in that direction, i.e., away from the idea of a public good and towards the idea of a private good. Those highly ranked global universities get easier access to policy makers across India and therefore not only redirect policy in all matters from health to extractive industries, but also get access to primary data in the government's records that national knowledge institutions find it difficult to access.

${ }_{17}$ See the recent debate on college admissions in the US, "Harvard and the False Premise of Meritocratic Admissions", in The Washington Post (www.washingtonpost.com/news/answer-sheet/ $\mathrm{wp} / 2017 / 08 / 10 /$ harvard-and-the-false-premise-of-meritocratic-university-admissions/?utm_term=. d06f14af1159). 
This can be seen - and this is my second illustration - in the increasing infiltration, by the global consultancy firms, of our policy making world. For example, some former members of the recently dissolved Planning Commission and of the Reserve Bank of India are now members of a major international consultancy group. If we consider this infiltration, this Trojan horse, as a pointer to how this comes about, and try and ascertain the number of All India Civil Service members who have joined global consultancy firms after taking early retirement, we would be very surprised indeed. From serving the nation to serving global capital, it appears, does not seem like a big step. It would be interesting to find out how many contracts have been given to these global consultancy firms by Ministries that have sought advice on policy, on the development road to be traversed, especially Ministries dealing with natural resources and extractive industries, at the levels of both the State and Union governments.

The reason given by the Ministries for awarding the contracts to firms in which they have ex-colleagues is that the consultancy firms are often the lowest bidders when tenders are called for. They have been selected in fair competition. Anecdotal evidence, however, suggests that very often such firms do not charge for the professional time of their highly paid staff in their quotations and, in their strategic calculus, are prepared to underwrite high 'cost to company' human resources so that they can get access to the ministry, its personnel, and its data archives. This is the asset they seek. This is the tangible capital (Ministry data) and the intangible capital (contacts) they acquire, which becomes very valuable when they service their private clients or when they service countries with whom India competes. Here their charges are very high and these private clients are willing to pay high rates for their professional time, since they are also now getting valuable information. If a correlation were to be found between the number of retired senior members of the civil service who become partners in these global consultancies after retirement and the number of consultancy contracts given to global firms, we would be in for a surprise. Unfortunately such data is not available because it has not yet been researched.

I am not suggesting mala fide by any individuals (this is easy to deal with), but wish primarily to draw attention to something more worrisome: the close association of the policy community with these firms who serve the interests of global capital. With their reports, policy briefs, analytical templates, seminars, foreign study tours, they produce in our policy makers a way of seeing, a set of beliefs on how to grow our economy. This serves the interests of global capital. No consultancy, for example, would tell us to ban vulture funds or disregard the recent decision, with respect to 
Argentina, of the US Supreme court on debt. The predatory forces which have grown in the last 20 years, inside and outside India, are a measure of the success of this recolonization of the policy mind. The consultancy firms are the Trojan horse of global capital.

The growing number and power of individuals and firms that has been the consequence of such policy thinking, has not just weakened the ability and willingness of states to reduce inequality, but also invisibilized the problems of poverty and destitution that were so much a part of policy thinking in India. ${ }^{18}$

The third example is the training programs, offered by the different training academies, directed at All India Civil Service officers at different levels of seniority. I was a member of the Programme Management Committee of the Lal Bahadur Shastri National Academy of Administration. In this institution, which trains the senior civil servants of India - the steel frame of the state-, a discussion is going on about the course content, pedagogy, and institutional collaboration with global universities. While I do not wish to elaborate on the internal discussions we have had, I can, however, mention my surprise when I learnt that one of the leading universities in the USA offered its professional time gratis for the training. I was puzzled by such altruism, since it is not available for students, who pay on average USD 55,000 per year to private universities in tuition. What then is the payoff? It can only be long term influence over our policy making. Again, it would be a valuable empirical exercise to document the number of such collaborations with leading northern private universities in the training programs of our All India Civil Service Officers. If the production of inferiority was the message of the first example, and the production of domination by global capital the message of the second example, the message of the third is the recolonization of policy institutions by the allies of global capital.

The three illustrations given here may seem to be isolated cases, but this is not so. Although they may appear random cases, they are, in fact, connected events and should be seen as illustrations of the deeper reality of global capital which has taken over our epistemic and policy spaces. Similarly to what happened during the colonial period, when knowledge institutions served the interests of the colonial regime, in India today the knowledge institutions and agencies promote the interests of global capital and do so in subtle and devious ways. They infiltrate our minds and dominate our ways of seeing. They control our public debate on which path is to be followed as we work toward better futures.

${ }_{18}$ A good illustration is the Prime Minister's trumpeting of India's rise of 42 places in the 'ease of doing business' but its dismal rank of 100 out of 119 in the Global Hunger Index is ignored. 
This dominant neo-liberal perspective which has established itself in India tells us how to organize our world, produce and distribute our wealth, and deploy the forces of the state such as the planning system, the regulation system, the judiciary, police, and the university. Since the 2014 General Elections in India this neoliberal perspective has gained immense traction. A scholar who tracks key words in the print media pointed out this domination to me. He referred to the debate on 'policy paralysis' that had preceded the election and that had gained widespread buy-in, making it a 'given' in our public discourse. We all believed there was 'policy paralysis'. He pointed out to me that this word always referred to policies that were favorable to the corporate sector or government policies that were considered to be stuck because of some public interest issue, such as reduction in the public subsidies on fertilizers, easier environmental clearances for extractive industries, etc. In these debates, he suggested, 'policy paralysis' never referred to policies on how to improve government schools, or government hospitals, or credit to indebted small farmers. ${ }^{19}$ Another example of such domination is the discussion, in the newspapers, on the welfare policies followed by the previous UPA government, which, it is held, produced beneficiaries who became the gravediggers of the very same government that benefitted them. ${ }^{20}$ People, it is argued, do not want handouts but want the economic opportunities that liberalization would allegedly bring. This idea too has now gained wide currency in the media.

If it sounds somewhat in the air to say that there are some malevolent institutions that serve as the praetorian guard of global capital, let me give this argument a concrete form and list the institutions that have so much power today and determine what the dominant development argument should be. These are the investment banks, the large global consultancies, the multilateral financial institutions, the credit rating agencies that determine the creditworthiness of a country and of a company - thereby enabling them to borrow from the financial markets - and of course the World Economic Forum at Davos. These ratings guide the international flow of financial capital, which in turn determines the investment decisions of multinational companies. Financial planners in government have many sleepless nights worrying about such ratings. If the ratings drop, then hundreds of millions of dollars flow out of the country, which in turn has a huge impact on the value of the currency. It is Wall Street and not Washington which runs the world.

\footnotetext{
${ }_{19}$ Vipul Mudgal in a private conversation with me.

${ }^{20}$ The United Progressive Alliance (UPA) is a coalition of center-left political parties in India, headed by the Indian National Congress.
} 
These core institutions of global capital are helped by the university, the think tank, the planning board, and the media corporation. Together they set the argument of what is to be done. They punish anyone who deviates from the line that they have set out with a threatened downgrade or a damaging report on a country's future. The day the Indian Parliament passed the Food Security Act, its currency, the rupee, lost 12 percent plus of its value against the dollar because of the concern that this would place an increased, and 'unjustifiable', burden on public finances. That it would give some food security to a few hundred million poor (nutrition deficiency and hunger is a big problem in India) was of little consequence to global capital. Now, after the 2014 General Election, the argument that we cannot afford a food security bill is being made boldly in public discourse, with calls being made for its reversal. It is an illustration of the domination of both the global public mind and the national public mind by the new colonizers of the mind in India. The new policy paradigm that is being aggressively argued for aims to produce a USA in India, not a Sweden or a Canada, just as in the earlier period the aim was to produce a Europe in India. The counterdiscourse, by scholars such as Drèze and Sen (2013) and Stiglitz (2014), is losing its constituency, for reasons which we must explore in terms of the sociology and political economy of knowledge which is producing this dominant episteme.

The first site is, quite naturally, the institutions of higher education. If we look both globally and nationally at these institutions we see that the university is being taken over by the logic of global capital. Let me quote from a lecture given by Martha Nussbaum: "The education of sympathy is being repressed once again today, as arts and humanities programs are increasingly being cut back in schools in many nations, in favor of a focus on technical and scientific education, which is seen as the key to a nation's financial success" (2007: 39). Nussbaum is arguing for a reversal of the logic in the innocent belief that her enlightened argument will persuade the managers of the university and the drivers of global capital to do otherwise. From the evidence it seems that she has been unsuccessful.

In India almost $95 \%$ of the new private universities that are coming up do not have programs in the arts and humanities but only in the technical subjects. New Indian Institutes of Technology (IITs) and Indian Institutes of Management (IIMs) are being set up and Regional Engineering Colleges (RECs) are being upgraded to become National Institutes of Technology (NITs). The new Central Universities have developed courses that again are biased in favor of the production of such instrumental knowledge. Similar trends mark the policy drivers of the European university, which was the 
initial inspiration for our own older universities. Boaventura de Sousa Santos, in his seminal essay, "The University at a Crossroads", describes the crises confronting the European university, asking whether it will produce citizens and knowledge which is critical, heterodox and non-marketable or whether it will produce "human capital subjected to market fluctuations like any other capital" (2012b: 15). Higher education policy in India is being driven by the logic of global capital to produce human capital, as can be seen in the National Knowledge Commission report on Higher Education. ${ }^{21}$

The best products of these institutions of higher education, especially the elite institutions, are then absorbed by the global consultancy firms, investment banks, rating agencies, think tanks and market survey firms. Through such recruitment they get a double benefit: good minds and a good network. This in itself is nothing to lament. In fact, if it is giving young people a job, then I have no argument with it.

But what is pernicious is that these user institutions have grown significantly and taken over our mind-space and thereby our policy making. The way this is done is through the informal networks they have established, networks of the college tie, through which they have privileged information on what is being planned at the higher levels of government and industry and through which they get the endorsements they require. When corporations begin to recruit fresh graduates from elite colleges, then you know that what you are witnessing is not just a process of co-option, defanging the political protesters of tomorrow as happened with those who came from such institutions in the nineteen sixties and seventies, but also the reproduction of the sustainable network of global capitalism.

The members of these institutions, because of their proximity to policy makers and because they succeed in winning the consultancies on offer, become the new producers of knowledge in the public sphere. Further, this knowledge, produced by the consultancy firms and investment banks, is not driven by the search for truth - which must meet the stringent requirements of the validity protocols of the social sciences -, but by the economic interests of the client, i.e., by the interests of global capital. None of these institutions would produce a study decrying the incentive structure of global capital on which compensation packages are based, arguing that it is unethical and unsupported by evidence and that the calculation of reward is whimsical and arbitrary. The recolonization of the mind masks the logic of global capital, which has produced an incentive system that is

${ }^{21}$ Available at http://knowledgecommissionarchive.nic.in/downloads/recommendations/ HigherEducationNote.pdf 
the basis of all key policy making. Such a logic has now begun to dominate the compensation packages in India.

Let us not be distracted by the argument that there are many logics of global capital - the Nordic logic, which has a welfarist dimension; the Japanese logic, which is paternalistic; the South European logic, which is state-centric. While all of these logics do have a particular historical-social presence, in a situation of conflict they lose out to the dominant logic of the incentive system that drives Wall Street. They become subservient to it. Does not the loss of Nokia by Finland show this? Does not Greece being beaten to its knees show this? Does not the new debate in Japan about abandoning its practice of life-long security for its workers show this? Does not China's and India's rising gini coefficient show this?

A discourse elite has emerged that dominates the production of the public mind. What they recommend dominates our mind-space. In fact, their view of the world has become normalized and this is what is alarming, because what is in fact ideological is being presented as the product of an evidence-based policy framework. My re-colonization of the mind argument will be read as too ideological by the leaders of the new public discourse, whereas, in fact, it is the other way around. This can only be demonstrated by winning the battle of counter-factuals that each side must produce. The colonization of the mind, in an earlier era, produced a feeling of inferiority and a desire, on the part of the colonized, to adopt the ideas of the colonizers. It was the enslavement of the mind. The recolonization of the mind today is having the same consequences.

Edited by João Paulo Moreira

\section{References}

Alvares, Claude (2001), Launching the Multiversity. Accessed at http://www.swaraj.org/ shikshantar/claudels3.htm

Benda, Julien (1955), The Betrayal of the Intellectuals. Boston: Beacon Press [orig. ed.: 1928].

Bhattacharya, Krishna Chandra (1954), "Swaraj in Ideas”, Visvabharati Quarterly, 20, 103-114 [orig. ed.: 1931].

Césaire, Aimé (1972), Discourse on Colonialism. New York: Monthly Review Press.

Chakrabarti, Arindam; Weber, Ralph (2015), Comparative Philosophy without Borders. London: Bloomsbury.

Chakrabarty, Dipesh (2000), Provincializing Europe: Postcolonial Thought and Historical Difference. Princeton: Princeton University Press. 
Cunha, Tristao de Braganza (1961), "Denationalization of Goans”, in Goa's Freedom Struggle. Bombay: Dr. T. B. Cunha Committee, 55-98 [orig. ed.: 1944].

Drèze, Jean; Sen, Amartya (2013), An Uncertain Glory: India and Its Contradictions. Princeton: Princeton University Press.

Dussel, Enrique (2013), “Agenda for a South-South Philosophical Dialogue”, Human Architecture, XI(1), 3-18

Fanon, Frantz (1967), Black Skin, White Masks. New York: Grove.

Foucault, Michel (1984), The Foucault Reader. New York: Pantheon.

Guha, Ranajit (1997), “On Some Aspects of the Historiography of Colonial India”, in Ranajit Guha; Gayatri C. Spivak (eds.), Selected Subaltern Studies. New York: Oxford University Press, 37-43 [orig. ed.: 1988].

Manguel, Alberto (2015), Curiosity. New Haven: Yale University Press.

Memmi, Albert (1992), The Pillar of Salt. Boston: Beacon Press [orig. ed.: 1955].

Mignolo, Walter (2002), "The Geopolitics of Knowledge and the Colonial Difference", South Atlantic Quarterly, 101(1), 57-92.

Moulvi, Abu-ur-Rashid (1888), “The Punjab University”, Asiatic Quarterly Review, 6, 63-101.

Nussbaum, Martha (2007), "Cultivating Humanity and World Citizenship", Forum for the Future of Higher Education, 37-40.

Parekh, Bhikhu C. (1999), Colonialism, Tradition, and Reform: An Analysis of Gandhi's Political Discourse. New Delhi: Sage.

Quijano, Anibal (2000), "Coloniality of Power, Eurocentrism, and Latin America", Nepentla: Views From the South, 1(3), 533-580.

Ramanujan, A. K. (1989), "Is there an Indian Way of Thinking? An Informal Essay", Contributions to Indian Sociology, 23(1), 41-58.

Rudolph, Susanne (2005), "The Imperialism of Categories: Situating Knowledge in a Globalizing World", Perspectives on Politics, 3(1), 5-14.

Said, Edward (1986), "Intellectuals in the Post-Colonial World", Salmangundi, 71/72, 44-64.

Said, Edward (2001), Reflections on Exile and Other Literary and Cultural Essays. London: Granta Books.

Santos, Boaventura de Sousa (2012a), "Public Sphere and Epistemologies of the South", Africa Development, 37(1), 43-67.

Santos, Boaventura de Sousa (2012b), "The University at a Crossroads", Human Architecture, X(1), 7-16.

Santos, Boaventura de Sousa (2014), Epistemologies of the South. Justice against Epistemicide. Boulder, CO: Paradigm.

Stiglitz, Joseph (2014), "Inequality is not Inevitable", The New York Times, June 27. Accessed at http://mobile.nytimes.com/blogs/opinionator/2014/06/27/ inequality-is-not-inevitable/?_php=true\&_type=blogs \&_r=0. 
Tagore, Rabindranath (1996), The English Writings of Rabindranath Tagore. Vol 2: Plays, Stories, Essays. New Delhi: Sahitya Akademi. Edited by Sisir Kumar Das.

Thiong'o, Ngugi wa (1986), Decolonizing the Mind. The Politics of Language in African Literature. London: Heinemann.

UNESCO (2015), Rethinking Education: Towards a Global Common Good? Paris: UNESCO.

Received on 04.08.2017

Accepted for publication on 17.10.2017

\section{Peter Ronald deSouza}

Centre for the Study of Developing Societies

29, Rajpur Road, Delhi 110054, India

Contact: peter@csds.in

\section{A recolonização da mente indiana}

Uma das consequências mais perniciosas do colonialismo foi o que K. C. Bhattacharya descreveu como a "escravidão das mentes”, que produziu um sentimento de inferioridade, um apagamento da memória e de culturas, um vocabulário conceptual estranho e uma perspetiva hegemónica com base na qual se olha o mundo. Este artigo descreve pormenorizadamente tais consequências para demonstrar os enormes desafios conceptuais que uma descolonização da mente tem que enfrentar para conseguir mudar a sociedade, e o discurso público, para um futuro verdadeiramente emancipatório. Para além desses desafios conceptuais, o artigo também descreve a nova e preocupante recolonização da mente indiana, que está a ser levada a cabo pelas agências produtoras de conhecimento - que estão fora da universidade e que são impulsionadas pelos interesses do capital global na sua

\section{La recolonisation de la pensée indienne}

L'une des conséquences les plus pernicieuses du colonialisme est ce que K. C. Bhattacharya décrivit comme l' "esclavage des pensées”, qui produisit un sentiment d'infériorité, un effacement de la mémoire et des cultures, un vocabulaire conceptuel étranger et une perspective hégémonique à partir de laquelle le monde est dès lors envisagé. Cet article décrit ces conséquences avec un certain détail afin de démontrer les énormes défis conceptuels auxquels une décolonisation des pensées est confrontée pour pouvoir affronter le changement de la société, tout autant que le discours public, pour un avenir véritablement émancipateur. En plus de ces défis conceptuels, l'article se penche aussi sur l'inquiétante nouvelle recolonisation de la pensée indienne qui est en train d'être mise en œuvre par les agences productrices de savoir en dehors des universités et qui sont 
implacável ambição de dominação. Essas agências de conhecimento produzem um discurso contaminado por interesses que, numa orientação completamente nova, está desligado da procura da verdade.

Palavras-chave: capital global; colonialismo; descolonização; Índia; K. C. Bhattacharya (1875-1949). mues par les intérêts du capital global en son implacable appétit de domination. Ces agences de savoir produisent un discours contaminé par des intérêts et qui est, dans une orientation totalement novatrice, détourné de la recherche de la vérité.

Mots-clés: capital global; colonialisme; décolonisation; Inde; K. C. Bhattacharya (1875-1949). 